\title{
ИСПОЛЬЗОВАНИЕ ТЕКСТУРИРОВАННЫХ ЗЕРНОВЫХ ПРОДУКТОВ В ПРОИЗВОДСТВЕ ОСНОВНОГО БИСКВИТА
}

\author{
M.A. Yanova, N.V. Prisukhina
}

\section{USING TEXTURED GRAIN PRODUCTS IN MAKING THE MAIN BISCUIT}

\begin{abstract}
Янова Марина Анатольевна - канд. с.-х. наук, доц. каф. товароведения и управления качеством продукции АПК Красноярского государственного аграрного университета, г. Красноярск. E-mail: yanova.m@mail.ru
\end{abstract}

Присухина Наталья Викторовна - канд. техн. наук, доц. каф. технологий хлебопекарного, кондитерского и макаронного производств Красноярского государственного аграрного университета, г. Красноярск. E-mail: nat3701@mail.ru

Перспективным направлением кондитерской отрасли является разработка бисквитных полусрабрикатов для тортов и пирожных с использованием нетрадиционных видов сырья. Важное место среди нетрадиционного сырья занимают текстурированные продукты. Цель работы - возможность использования зерновых текстуратов в производстве бисквитов сбивных. В результате обработки зерновых культур экструзией в сырье происходят изменения на молекулярном уровне. Белки зерновых денатурируют, способствуя лучшему усвоению организмом. Появляется приятный вкус и ореховый аромат. В процессе проведения исследования изучали влияние смеси из пшеничной муки и текстуратов из экструдированного зерна ячменя, пшеницы и овса. В бисквитный полуфрабрикат смесь вносили вместе с мукой на стадии замеса теста в дозировках 15, 20 и 25 \%. Плотность теста при внесении текстуратов практически не менялась и оставалась в пределах погрешности опыта. В готовых изделиях определяли основнье показатели качества. С увеличением дозировки текстуратов в образцах бисквита наблюдалось увеличение влажности, уменьшение пористости и увеличение удельного объема. Показатели качества готовых бисквитов соответствовали нормам. По ре-
Yanova Marina Anatolyevna - Cand. Agr. Sci., Assoc. Prof., Chair of Merchandizing and Product Quality Control of AIC, Krasnoyarsk State Agrarian University, Krasnoyarsk.

E-mail: yanova.m@mail.ru

Prisukhina Natalya Victorovna - Cand. Techn. Sci., Assoc. Prof., Chair of Technologies of Baking, Confectionery and Macaroni Productions, Krasnoyarsk State Agrarian University, Krasnoyarsk.

E-mail: nat3701@mail.ru

зультатам дегустационной оценки наивысшие баллы набрали образцы бисквита с добавлением 20 \% текстурата ячменя и пшеницы и $15 \%$ текстурата овса. На последнем этапе исследования изучено влияние текстуратов на массовую долю влаги во время хранения при темnературе $18-20{ }^{\circ} \mathrm{C}$. При хранении образцов установлено, что наибольшие изменения массовой доли влаги и массы изделий происходили в контрольном образце, т.е. с увеличением добавки текстурата очерствение происходило медленнее. Таким образом, данные проведенных исследований показали, что частичная замена пшеничной муки на текстураты из экструдированных зерновых культур оказываem положительное влияние на качество бисквитных полусрабрикатов.

Ключевые слова: текстурат, экструдированное зерно, ячмень, овес, пшеница, бисквит, качество, ценность.

A promising direction of the confectionery industry is the development of biscuit semi-finished products for cakes and pastries using non-traditional types of raw materials. An important place among unconventional raw materials is occupied by textured products. The aim of the study is discussing the possibility of using grain texture in the production of whipped biscuits. The processing of grain crops 
extrusion in raw materials result in their change at molecular level. The proteins of grain denature, contribute to better absorption by an organism. There is a pleasant taste and nutty aroma. During the research the effect of the mixture of wheat flour and textures from extruded grain of barley, wheat and oats has been studied. The mixture is added to the biscuit semi-finished cake mix along with the flour at the stage of kneading dough in the dosages of 15 , 20 and $25 \%$. Dough density at introduction of texturates practically does not change and remain within experimental error. In finished products the main quality indicators are determined. With an increase in the dosage of texture in biscuit samples, an increase in humidity, a decrease in porosity, and an increase in specific volume are observed. Quality indicators of finished biscuits corresponds to the standards. According to the results of tasting assessment the highest scores are obtained for biscuit samples with the addition of $20 \%$ of barley and wheat texture and $15 \%$ of oat texture. At the last stage of the research the effect of texture on the mass fraction of moisture during storage at the temperature of $18-20^{\circ} \mathrm{C}$ has been studied. Storing the samples it is found out that the greatest changes in the mass fraction of moisture and the mass of the products has occurred in the control sample, i.e. with an increase in the addition of the texture the staling has been slower. Thus, the data of the studies shows that partial replacement of wheat flour with the textures from extruded crops has had a positive effect on the quality of biscuit semi-finished products.

Keywords: texturate, extruded grain, barley, oats, wheat, biscuit, quality, value.

Введение. Использование разнообразных растительных ингредиентов в рецептурах кондитерских изделий способствует повышению питательности и усвояемости, при этом в них достаточно низка минеральная и витаминная ценность. Весомую часть в ассортименте кондитерских изделий занимает группа мучных изделий. Поэтому разработка новых видов мучных кондитерских изделий, в частности сбивных бисквитов, используемых для производства тортов и пирожных, а также рулетов, является перспективным направлением [1, 2].

В числе нетрадиционных видов сырья для создания новых видов кондитерских изделий важное место занимают текстурированные продукты из зернового сырья [3, 4].

Бисквитное тесто относится к слабоструктурированному. Качество бисквитного теста определяется свойствами взбитой яично-сахарной массы и белковых веществ муки, способных набухать [5].

Зерна увлажненного крахмала и набухшие нерастворимые в воде белки составляют твердую фазу теста. Жидкая фраза бисквитного теста состоит из многокомпонентного водного раствора сахара, меланжа и поверхностно-активных веществ. В жидкую фразу при замесе теста частично переходят органические и минеральные водорастворимые части муки. На замес классического бисквита не расходуется вода. В присутствии перечисленных компонентов жидкой фразы, которые отличаются гидратационной способностью, значительная часть воды находится в связанном состоянии, поэтому на набухание белков расходуется значительная часть жидкой фазы.

Муку при замесе бисквитного теста вводят во взбитую яично-сахарную смесь в конце для снижения набухания белков, так как продолжительный замес с мукой приводит к более упругой и жесткой структуре готового бисквита. Для бисквита предпочтительнее использовать муку со слабой клейковиной. Добавление крахмала в бисквитное тесто предохраняет его от затягивания.

Цель работы. Изучение влияния текстуратов из экструдированного зерна ячменя, пшеницы и овса на качество и сроки хранения основного бисквита.

Задачи исследования: разработать рецептуры бисквита с добавлением текстурированных продуктов из экструдированного зерна пшеницы, ячменя, овса; исследовать разработанный бисквит на качество, сроки хранения бисквита.

Объекты и методы исследования. Контроль - бисквит основной и опытные образцы - бисквит из смеси пшеничной муки и текстуратов ячменя, пшеницы и овса в количестве от 15 до $25 \%$.

Работу проводили с помощью общепринятых методик исследования: определение влажности выпеченного полуфабриката - по ГОСТ 5900; определение пористости - по ГОСТ 5669-96. Органолептическую оценку выпеченных изделий проводили по 10-балльной шкале [3]. 
Результаты исследования и их обсуждение. В результате обработки зерна экструзией происходят молекулярные изменения крахмальных зерен, денатурируют белки, меняются водои жироудерживающие свойства $[6,7]$. Белки текстурированных продуктов легче усваиваются, они имеют богатый аминокислотный состав. Тек- стурированное зерно имеет высокие органолептические показатели.

Бисквит готовили по традиционной технологии путем сбивания яично-сахарной смеси с последующим добавлением смеси муки и крахмала, а также смеси текстурата (рис. 1).

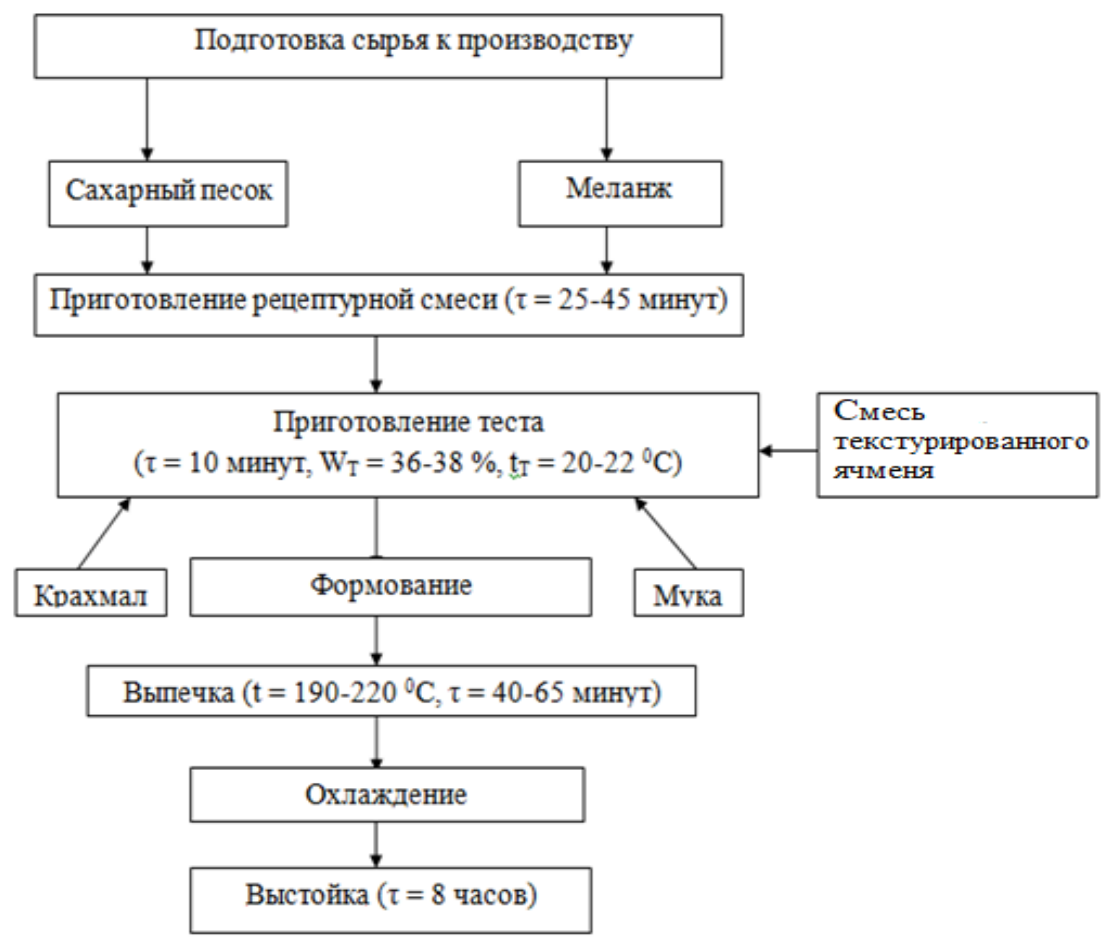

Puc. 1. Схема производства бисквита

На первом этапе определяли влияние количества замены текстурированной смеси ячменя, пшеницы и овса на плотность теста из муки пшеничной высшего сорта. Замену проводили в количестве 15, 20 и $25 \%$ от массы муки пшеничной. На рисунках 2-4 приведена плотность теста в зависимости от дозировки текстуратов.

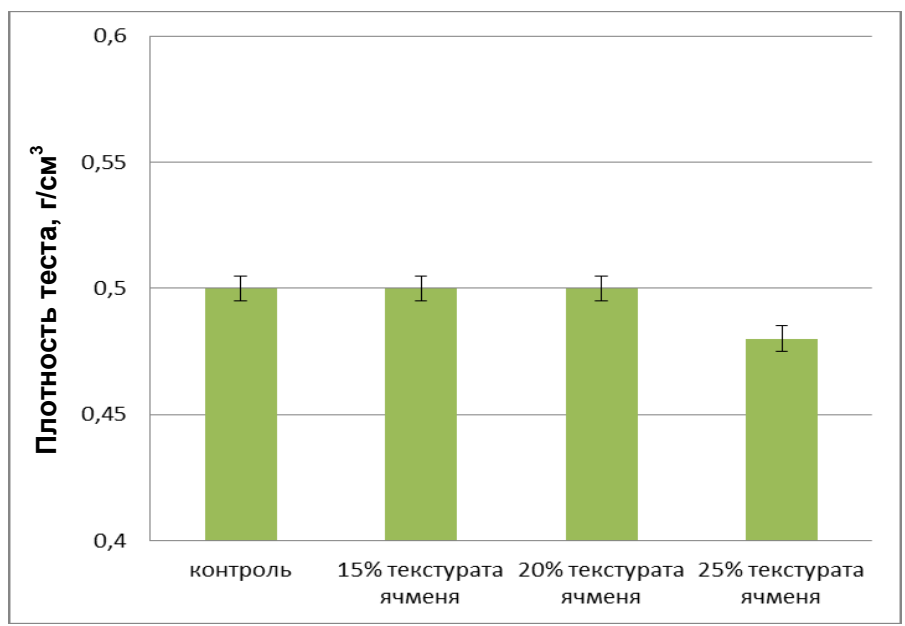

Puc. 2. Плотность теста после замеса с текстуратом из ячменя, г/см³ 


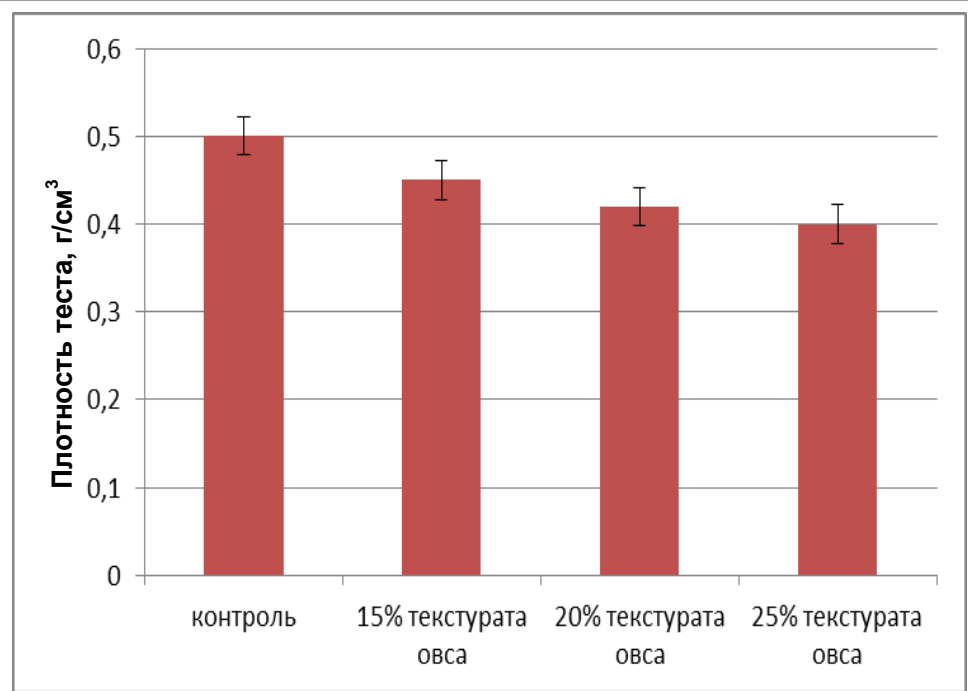

Puc. 3. Плотность теста после замеса с текстуратом из овса, г/см³

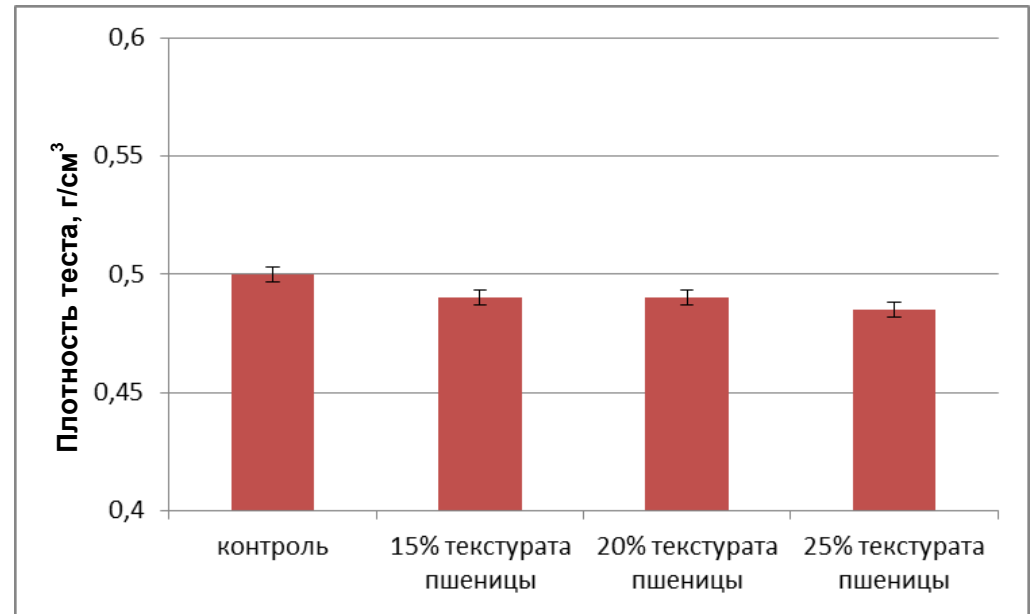

Puc. 4. Плотность теста после замеса с текстуратом из пшеницы, г/см³

Результаты показывают, что плотность теста остается на уровне контрольного образца. В образце с текстуратом из ячменя плотность бисквита уменьшается всего на 0,02 г/см³ при внесении $25 \%$ текстурированной смеси. В образце с текстуратом из овса происходит более заметное уменьшение плотности с 0,5 в контроле до 0,4 г/см³ в образце с заменой на $25 \%$ текстурированной смеси. С заменой текстурата пшеничного наблюдалось самое незначительное изме-

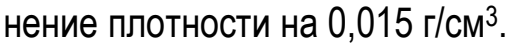

На втором этапе изучали качество полученных бисквитов с заменой муки на смеси из зерновых текстуратов.

Исследовали органолептические и физикохимические показатели качества в бисквитах.
Органолептическая оценка проводилась по 10балльной шкале с участием 5 членов дегустационной комиссии. По результатам дегустационной оценки построены лепестковые диаграммы (рис. 5-7), из которых видно, что наивысшую оценку получили: образец с заменой муки пшеничной на текстурат ячменя в количестве $20 \%$, образец с заменой муки пшеничной на текстурат овса в количестве $15 \%$ и образец с заменой муки пшеничной $20 \%$ на текстурат пшеничный. На рисунке 8 представлены результаты сравнительной дегустационной оценки лучших образцов бисквитов с текстуратами из разных зерновых культур. 


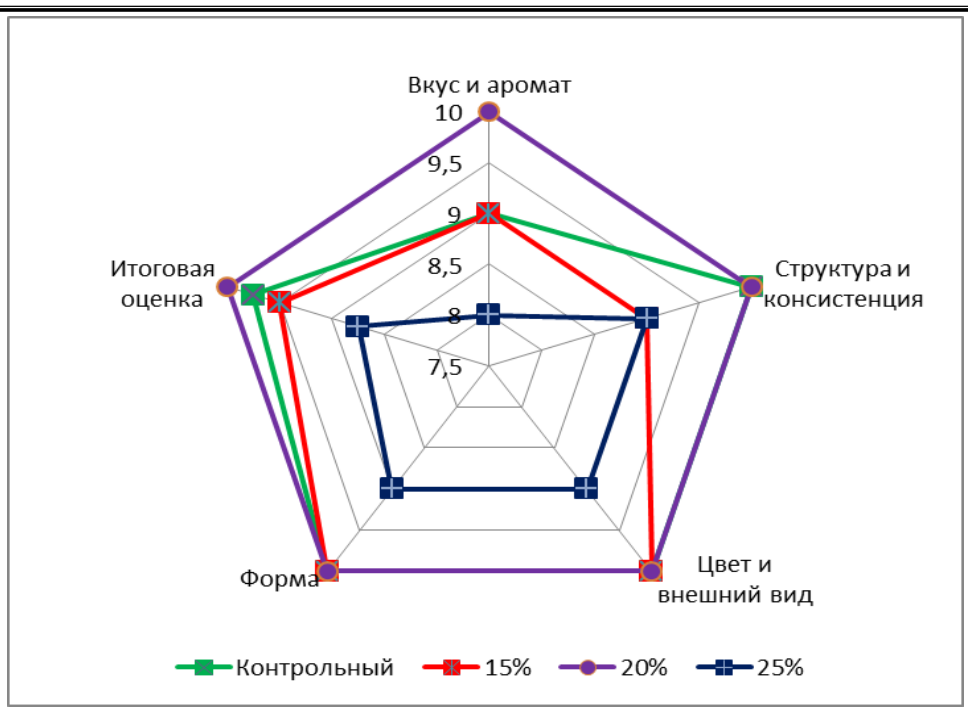

Рис. 5. Результаты дегустационной оценки бисквита с текстуратом из ячменя

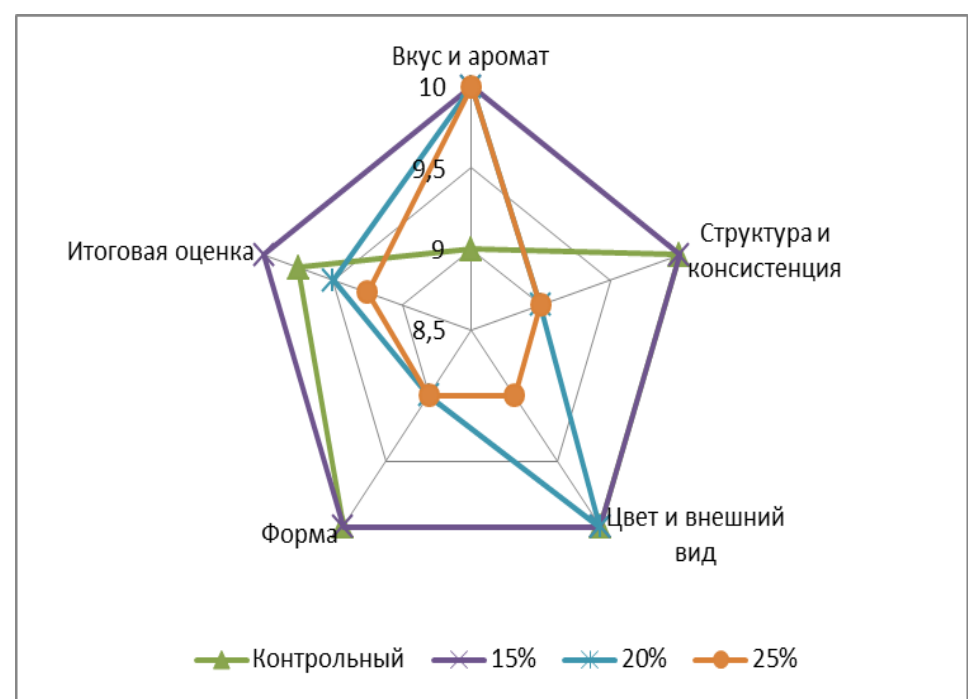

Puс. 6. Результаты дегустационной оценки бисквита с текстуратом из овса

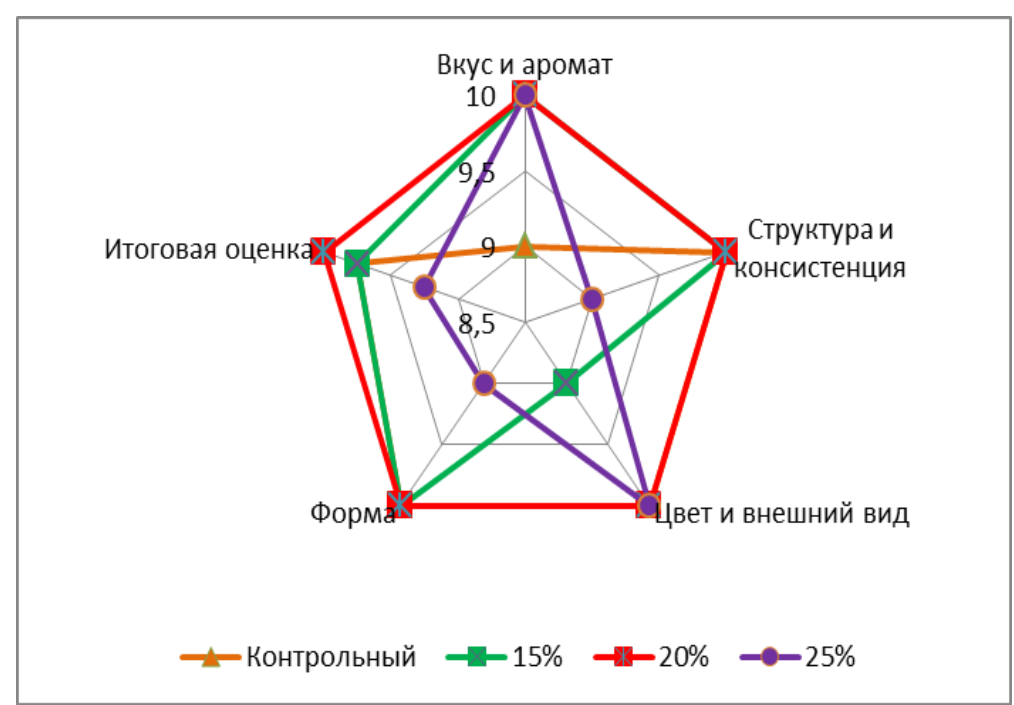

Puс. 7. Результаты дегустационной оценки бисквита с текстуратом из пшеницы 


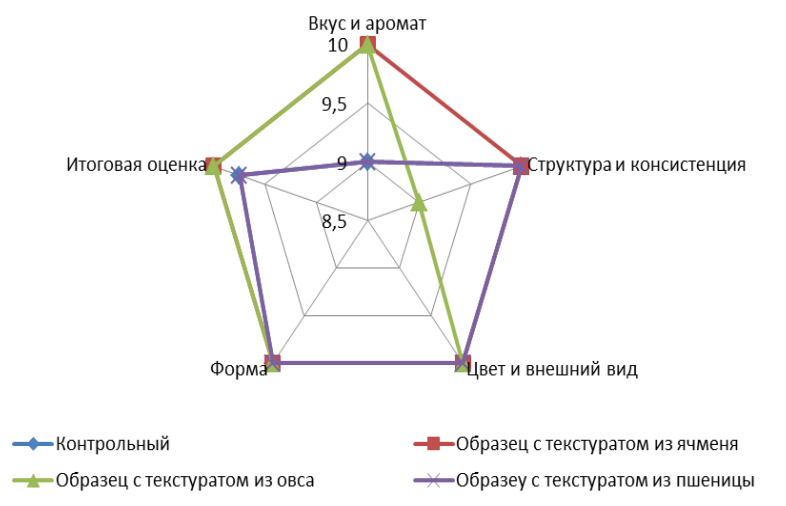

Рис. 8. Результаты сравнительной дегустационной оценки бисквитов с текстуратами

Через 8 ч выстойки бисквитные полуфабри- дозировкой в $15 \%$, на 0,5 с дозировкой $20 \%$ каты исследовали по следующим физико- смеси текстурата и на 0,7 с 25 \% смеси текстухимическим показателям: удельный объем, рированного ячменя относительно контроля. влажность и пористость (рис. 9-14).

В образцах бисквита с текстуратом ячменя дозировки текстурата ячменя уменьшается, но наблюдается увеличение влажности на 0,3 с совсем незначительно.

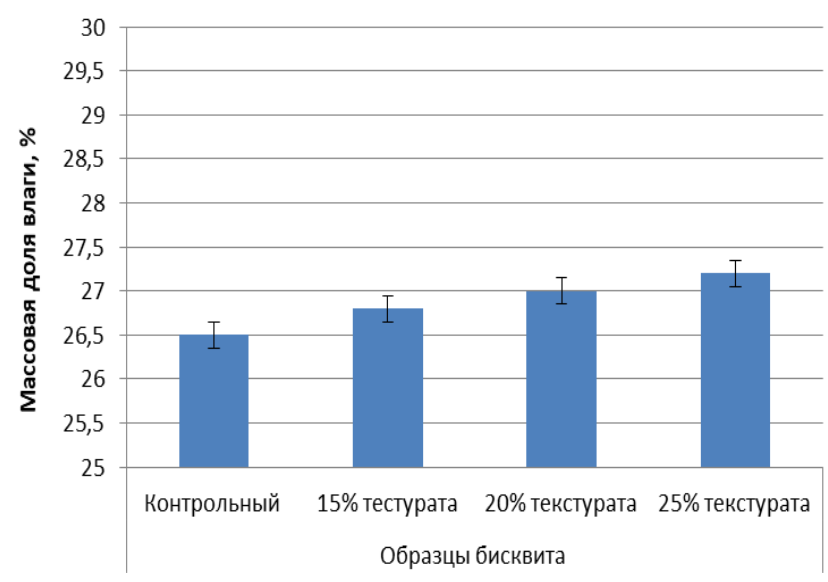

Puc. 9. Массовая доля влаги образцов бисквита с текстуратом из ячменя

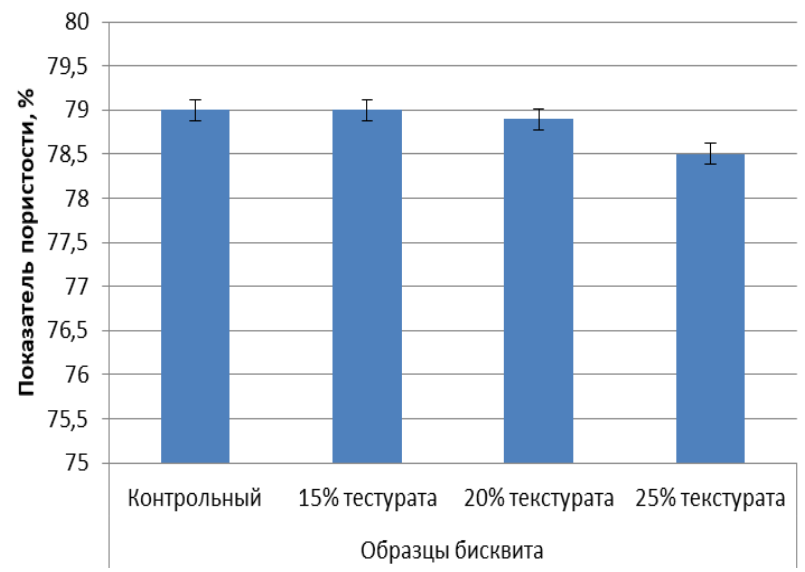

Puс. 10. Пористость образцов бисквита с текстуратом из ячменя 


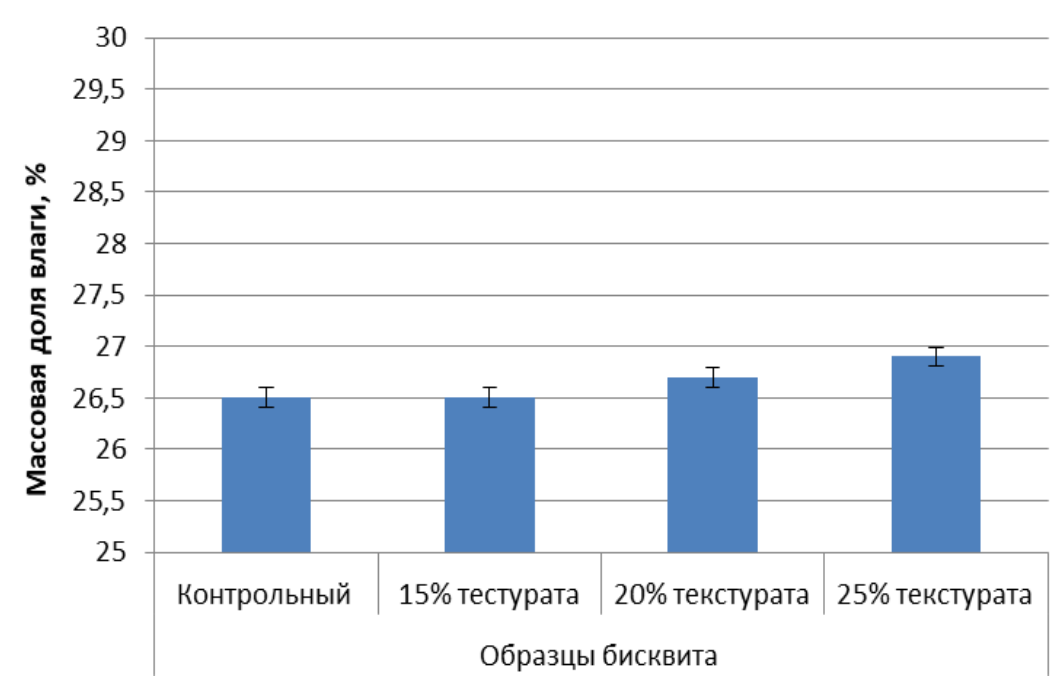

Puc. 11. Массовая доля влаги образцов бисквита с текстуратом из пшеницы

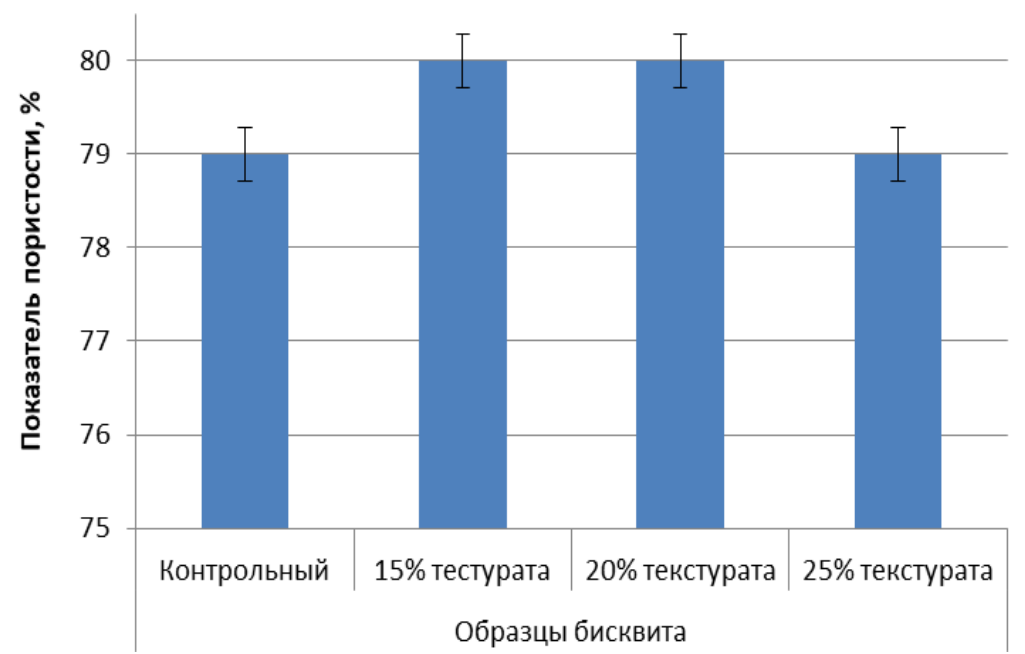

Puc. 12. Пористость образцов бисквита с текстуратом из пшеницы

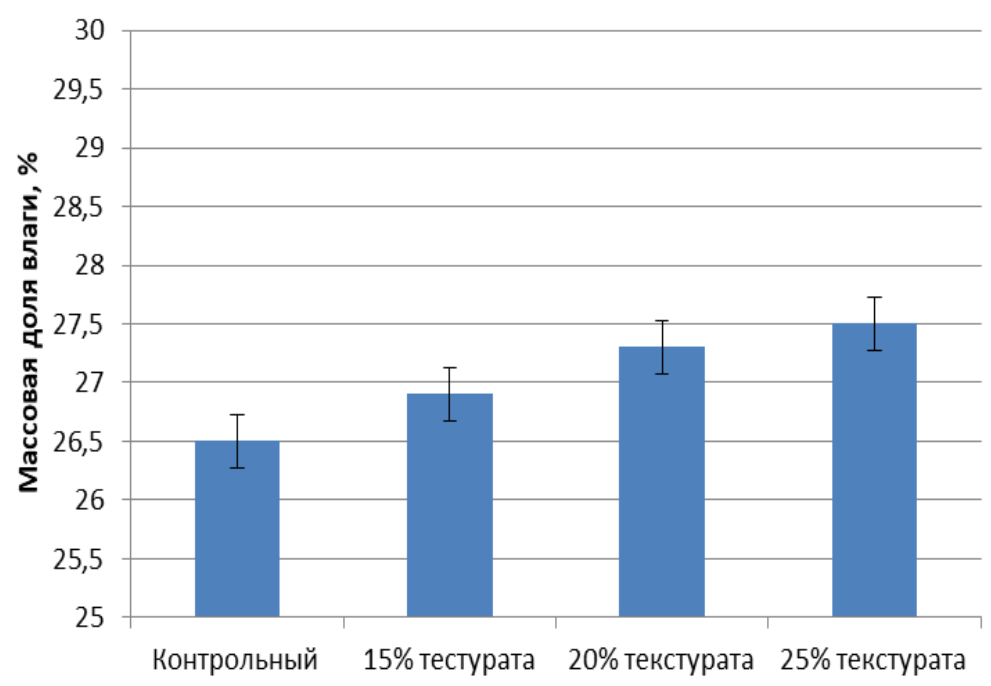

Puc. 13. Массовая доля влаги образцов бисквита с текстуратом из овса 


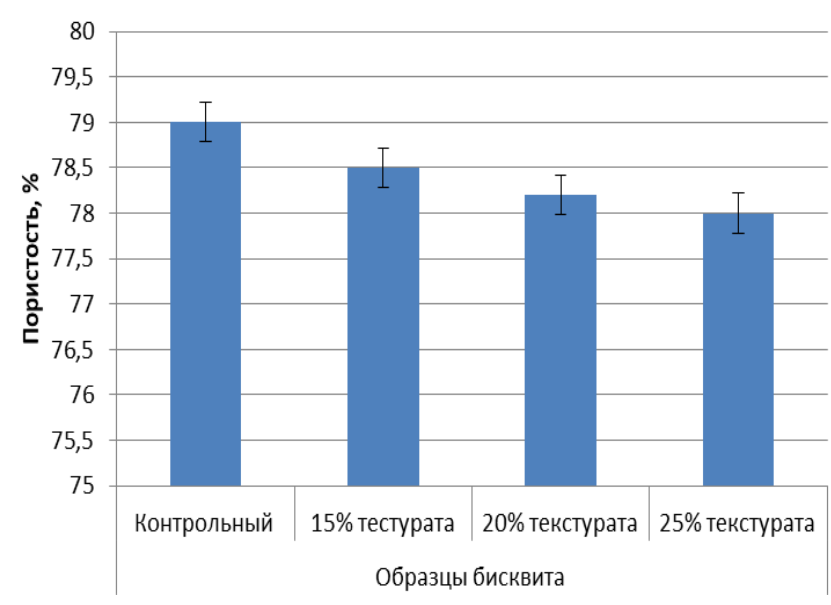

Puc. 14. Пористость образцов бисквита с текстуратом из овса

Показатели удельного объема бисквитов показывают, что добавление текстуратов не оказывает значительного воздействия. С увеличе- нием дозировки повышается удельный объем бисквитных полуфрабрикатов (рис. 15-17).

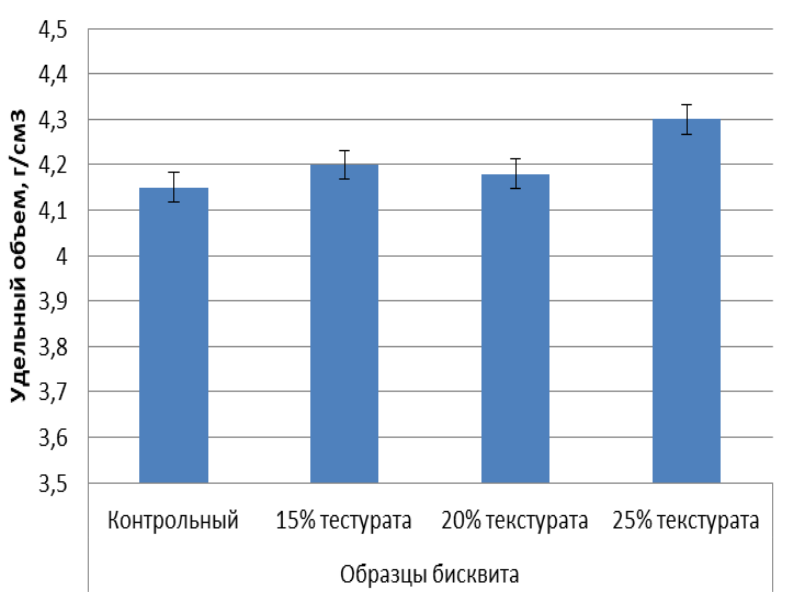

Puc. 15. Изменение удельного объема в зависимости от дозировки смеси текстурата ячменя

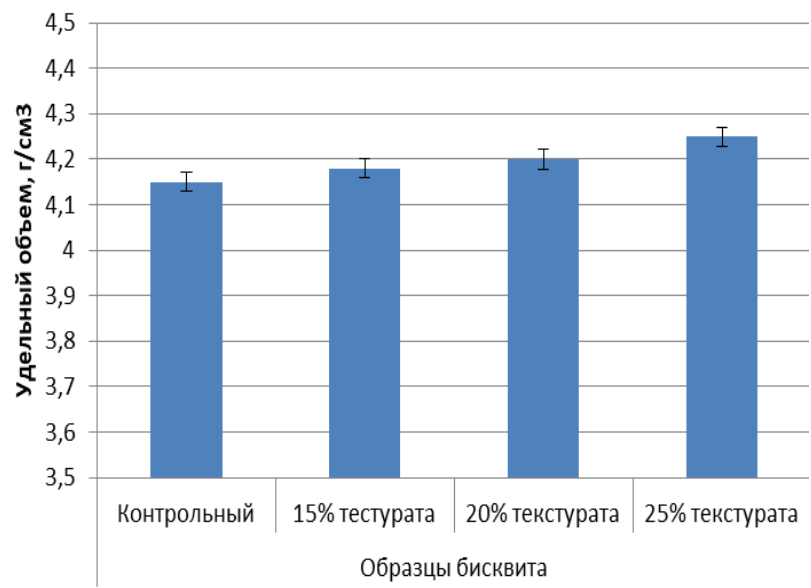

Puс. 16. Изменение удельного объема в зависимости от дозировки смеси текстурата пшеницы 


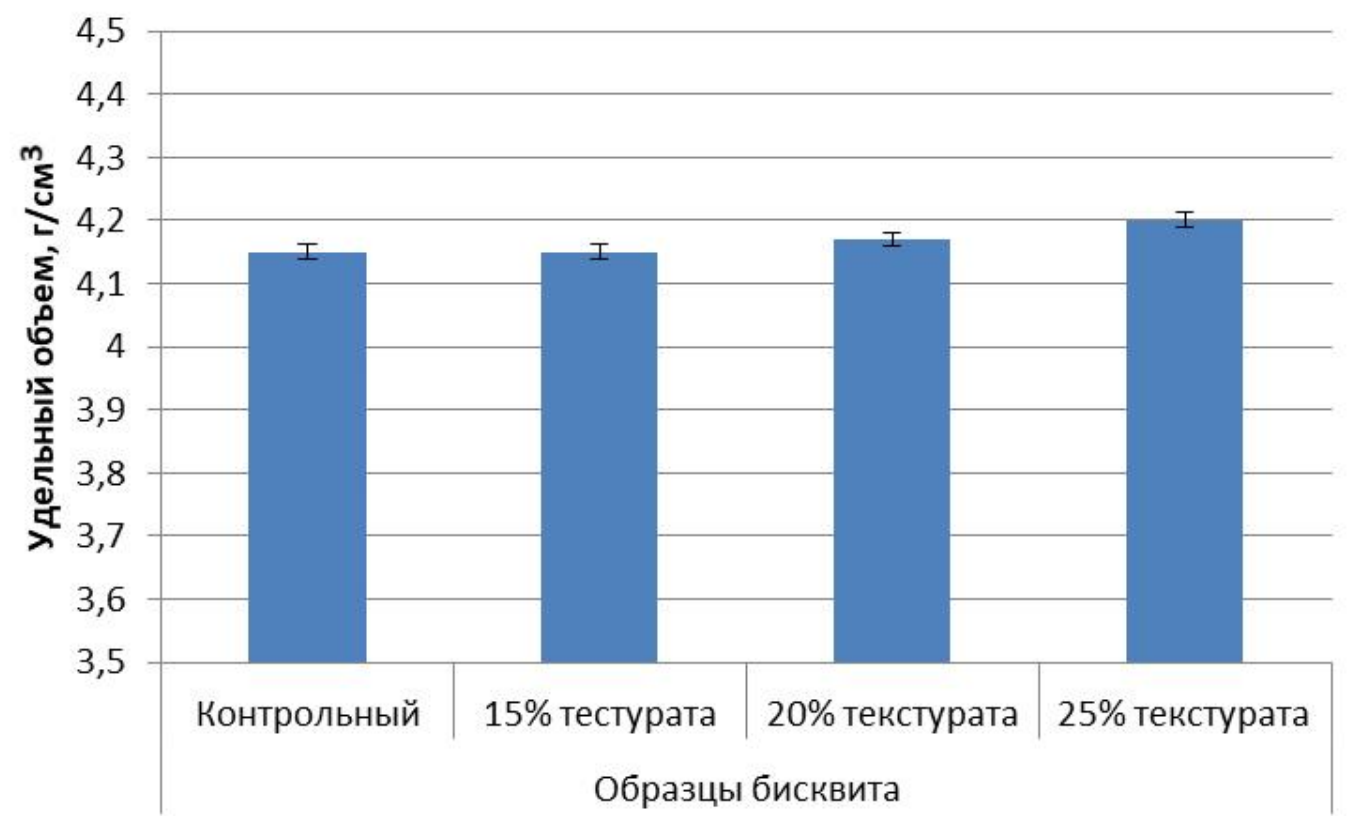

Puс. 17. Изменение удельного объема в зависимости от дозировки смеси текстурата овса

Изменения ффизико-химических показателей остаются в пределах требований стандартов. Но добавление свыше 20 \% текстурата ухудшает органолептические показатели бисквитных полуфрабрикатов. Таким образом, экспериментально обосновано, что наиболее оптимальным вариантом является замена 20 \% муки на текстуриро- ванную смесь из ячменя, пшеницы, при использовании текстурата из овса наиболее высокими показателями обладает образец с 15 \% текстурата.

На третьем этапе проведен сравнительный анализ изменения в процессе хранения влажностии массы готовых изделий (рис. 18, 19).

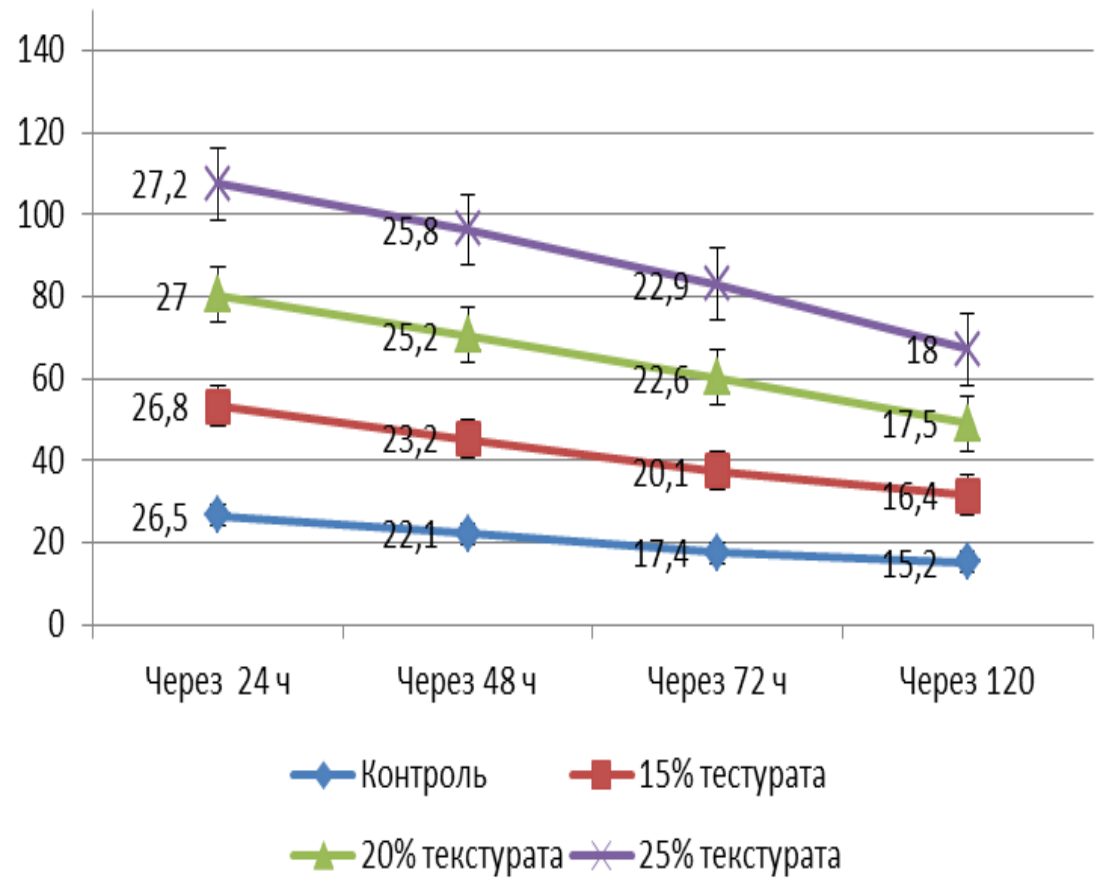

Рис. 18. Изменение влажности бисквитных полуфрабрикатов во время хранения 


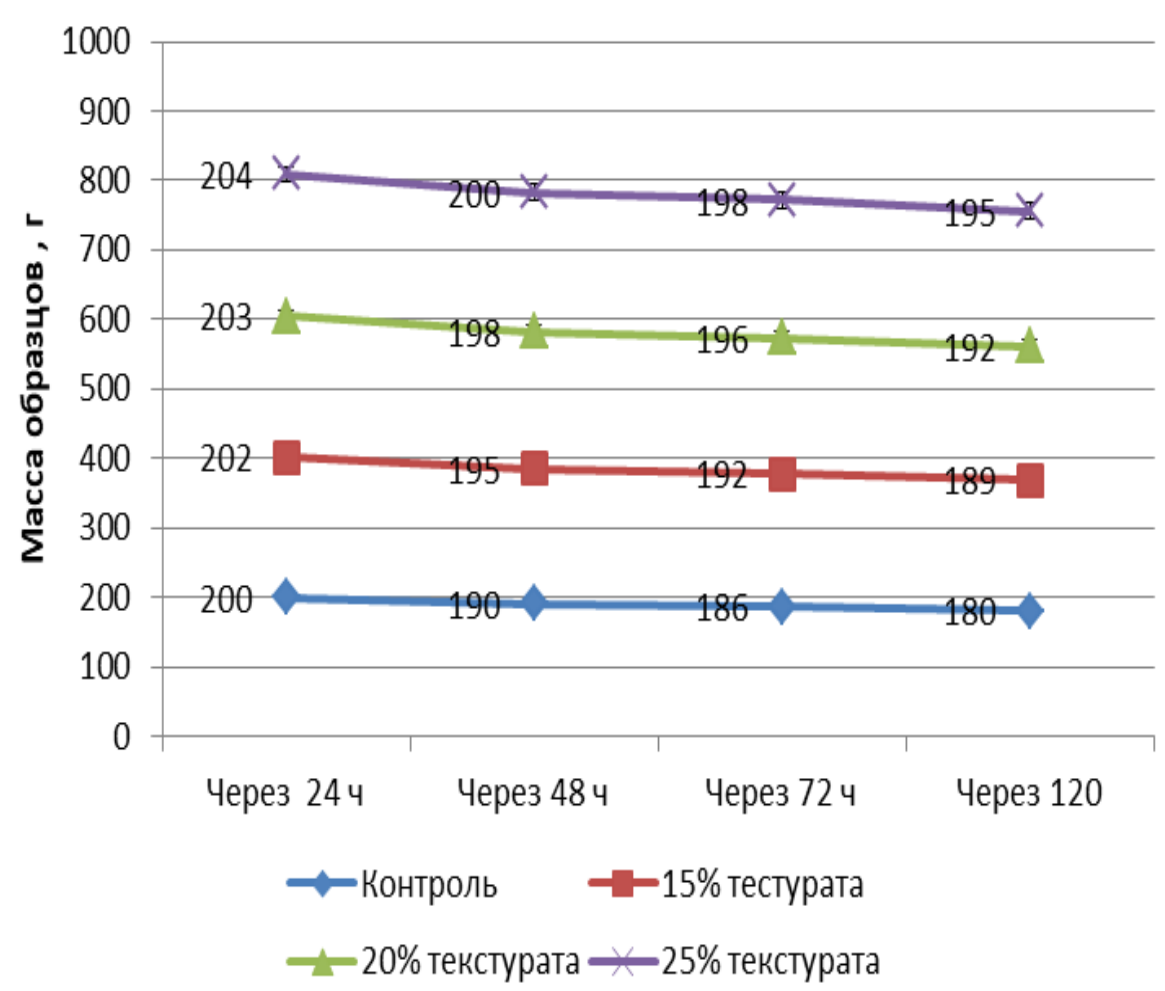

Puс. 19. Изменение массы бисквитных полуфрабрикатов во время хранения

При хранении образцов при температуре 18$20{ }^{\circ} \mathrm{C}$ установлено, что через 120 часов хранения наибольшее уменьшение массовой доли влаги в бисквите и массы изделий происходило в контрольном образце. Срок хранения бисквита увеличивается на 24 часа по сравнению с изделиями, произведенными по традиционной рецептуре, и составляет 144 часа.

Выводы. Таким образом, данные проведенных исследований показали, что частичная замена пшеничной муки на смесь из текстурированных продуктов из зерновых культур оказывает положительное влияние на качество бисквитных полуфабрикатов при замене в рецептурах бисквитов муки пшеничной высшего сорта на текстураты в количестве от 15 до $20 \%$ от массы муки. Новые виды бисквита обладают хорошими органолептическими показателями, появляется ореховый привкус. Пористость и влажность полусабрикатов остаются в пределах норм стандартов. Процессы черствения изделий замедляются, что положительно сказывается на сроках хранения продукта. Разработанные полуфабрикаты можно использовать для производства различных тортов, пирожных и рулетов для всех групп населения.

\section{Литература}

1. Пащенко В., Магомедов Г., Ермоленко Т. Использование цельносмолотой муки из плодов боярышника в технологии бисквита // Хлебопродукты. - 2011. - № 6. - С. 38-39.

2. Воронина М.С., Макарова Н.В. Исследование содержания первичных и вторичных продуктов окисления в жировой фразе белого масляного бисквита // Проблемы экономики и управления в торговле и промышленности. 2014. - № 4 (8). - C. 83-86.

3. Ермош Л.Г., Присухина Н.В., Казина В.В. Использование порошка из ягод ирги в качестве заменителя сахара в производстве мучных кондитерских изделий // Вестник КрасГАУ. - 2019. - № 12. - С. 131-138.

4. Ладнова О.Л., Меркулова Е.Г., Извекова Е.В. [и др.]. Современные технологии получения мучных кондитерских изделий на основе бисквита функцционального назначения // Вестник ОрелГИЭТ. - 2015. - № 1 (31). C. 133-137.

5. Корячкина С.Я., Лазарева Т.Н., Кабанова Т.В. [и др.]. Использование нетрадиционного сы- 
рья в технологии бисквита // Хлебопродукты. - 2015. - № 6. - C. 44-45.

6. J. Grebaut Cuisson - extrusion des produitscerealiers // Industries des cereales. -1984. № 28. - S. 7-12.

7. Янова М.А., Присухина Н.В., Горбунова Т.А. Влияние текстурированных продуктов из зернового сырья на состояние углеводноамилазного комплекса в мучных смесях для хлебобулочных изделий // Вестник КрасГАУ. - 2019. - № 11. - С. 127-132.

\section{Literatura}

1. Pashchenko V., Magomedov G., Ermolenko T. Ispol'zovanie cel'nosmolotoj muki iz plodov boyaryshnika $\mathrm{v}$ tekhnologii biskvita // Hleboprodukty. - 2011. - № 6. - S. 38-39.

2. Voronina M.S., Makarova N.V. Issledovanie soderzhaniya pervichnyh i vtorichnyh produktov okisleniya $\mathrm{v}$ zhirovoj faze belogo maslyanogo biskvita // Problemy ekonomiki i upravleniya $\mathrm{v}$ torgovle i promyshlennosti. 2014. - № 4 (8). - S. 83-86.
3. Ermosh L.G., Prisuhina N.V., Kazina V.V. Ispol'zovanie poroshka iz yagod irgi $V$ kachestve zamenitelya sahara $v$ proizvodstve muchnyh konditerskih izdelij // Vestnik KrasGAU. - 2019. - № 12. - S. 131-138.

4. Ladnova O.L., Merkulova E.G., Izvekova E.V. [idr.]. Sovremennye tekhnologii polucheniya muchnyh konditerskih izdelij na osnove biskvita funkcional'nogo naznacheniya // Vestnik OrelGIET. - 2015. - № 1 (31). - S. 133-137.

5. Koryachkina S.Ya., Lazareva T.N., Kabanova T.V. [i dr.]. Ispol'zovanie netradicionnogo syr'ya v tekhnologii biskvita // Hleboprodukty. 2015. - № 6. - S. 44-45.

6. J. Grebaut Cuisson - extrusion des produitscerealiers // Industries des cereales. -1984. № 28. - S. 7-12.

7. Yanova M.A., Prisuhina N.V., Gorbunova T.A. Vliyanie teksturirovannyh produktov iz zernovogo syr'ya na sostoyanie uglevodnoamilaznogo kompleksa $v$ muchnyh smesyah dlya hlebobulochnyh izdelij // Vestnik KrasGAU. - 2019. - № 11. - S. 127-132. 